\title{
CAUSAL CORRELATIONS BETWEEN GENES AND LINGUISTIC FEATURES - THE MECHANISM OF GRADUAL LANGUAGE EVOLUTION
}

\author{
DAN DEDIU \\ Linguistics and English Language, University of Edinburgh, 40 George Square \\ Edinburgh, EH8 9LL, UK
}

\begin{abstract}
The causal correlations between human genetic variants and linguistic (typological) features could represent the mechanism required for gradual, accretionary models of language evolution. The causal link is mediated by the process of cultural transmission of language across generations in a population of genetically biased individuals. The particular case of Tone, ASPM and Microcephalin is discussed as an illustration. It is proposed that this type of genetically-influenced linguistic bias, coupled with a fundamental role for genetic and linguistic diversities, provides a better explanation for the evolution of language and linguistic universals.
\end{abstract}

\section{Language evolution as a gradual, accretionary process}

There are many controversies concerning the evolution of language from a primitive, language-less state shared with the rest of the animal kingdom, to a derived one characterized by modern language, specific to our own species, Homo sapiens ${ }^{a}$. Simplifying, the main divides across the field seem to concern:

i. the nature of the transition: catastrophic (Crow, 2002a, b) versus gradual/accretionary (Pinker \& Jackendoff, 2005; Smith, 2006; or Hurford, 2003);

ii. the timing: recent (Crow, 2002a, b) versus ancient (Hurford, 2003);

iii. the protolanguage: holistic (Kirby, 2000 or Wray, 2000, 2002) versus synthetic (Tallermann, 2006, Bickerton 2000),

but few theories address all these aspects at the same level of detail.

As argued extensively elsewhere (Dediu, 2006; Dediu, 2007), the model of human evolution considered, whether explicitly or implicitly, strongly

\footnotetext{
a See, for example, the multitude of opinions expressed during the EvoLang conferences: Hurford, Studdert-Kennedy \& Knight, 1998; Knight, Studdert-Kennedy \& Hurford, 2000; Cangelosi, Smith \& Smith, 2006; or in Christiansen \& Kirby, 2003, to cite just a few relevant works.
} 
constrains the class of language evolution models envisageable. For example, a strong adherence to the extreme Out-of-Africa with Replacement model ${ }^{b}$ (Stringer \& Andrews, 1988) will favor a recent, catastrophic view of the evolution of language, in the vein of Crow (2002a, b). Of course, there is also a much weaker reciprocal influence, informing the human evolutionary models with data, theories and speculations originating from the considered model of language evolution.

If we suspend the assumption of a punctual speciation event for modern humans, the consequences for language evolution models are overwhelming (Dediu, 2006, 2007). This requirement of a recent speciation event has placed strong constraints on both the temporal span and the amount of diversity (genetic and cultural) available for evolving language(s), which has lead, in turn, to a very limited set of compatible proposals, namely either a hopeful monster (FOXP2, protocadherinXY) or a purely cultural process (compositionality as a result transmission bottlenecks).

However, even with a large degree of phenotypic plasticity (especially at the neural level), it is hard to accept that a single lucky mutation could have created modern language out of a radically different precursor, irrespective of the proposed mechanisms (Mithen's (1996) "cognitive fluidity", Crow's (2002b) "lateralization", etc.). The difficulty stems from the current data and theories concerning the biological limits of phenotypes generated by catastrophic mutations (West-Eberhard, 2003; Dawkins, 1997; Skelton, 1993; Gerhart \& Kirschner, 1997), the behavioral genetics of language arguing for an important genetic component (accounted for by many genes with small effects, comprising both generalists and specialists, most of them involved in more than one aspect of language, or, generally, cognition; Stromswold, 2001; Bishop, 2003; Fisher, Lai \& Monaco, 2003; Plomin \& Kovas, 2005) and the fact that the indissoluble link between modern humans and modern language, based on a specifically modern "package", does not seem to hold (Dediu, 2006, 2007). The theories arguing for a purely cultural process (Kirby, 2000) still seem to implicitly assume that biological evolution provided the cognitive processes (potentially, non-language specific) required for a proper cultural evolution of language. But, given the apparently very general requirements (Kirby, 2000; Brighton, 2003), one is left to wonder if this really demands a modern brain at all (Dediu, 2007).

\footnotetext{
b Positing a recent, punctual origin of modern humans in Africa and subsequent spread across the world with replacement of the pre-existing humans and without admixing with them.
} 
Given the previous discussion and the more detailed criticisms in Dediu (2006, 2007), it is proposed that a gradual, accretionary model for language evolution, covering an extensive period of time ${ }^{\mathrm{c}}$, offers a better alternative. This model is fundamentally based on genetic and cultural diverse populations, involved in a dynamic network of interactions (Dediu, 2007), whereby populations are continuously expanding, contracting, becoming extinct and being replaced, but in permanent contact with other such populations, and part of regional and global networks of genetic and cultural exchanges. Inter-individual and interpopulation diversities are thus essential ingredients, and not just some form of noise which must be filtered out in order to gain access to the core, universal properties of interest. It can be said that it is through complex interactions between diverse components that universals arise, in the first place.

However, the only missing fundamental ingredient for such gradual, accretionary models of language evolution is represented by the small, Darwinian genetic changes.

\section{Linguistic and genetic causal correlations - the case of linguistic tone, $A S P M$ and Microcephalin}

More explicitly, how do these gradual, accretionary steps of language evolution look like? They must certainly involve both genetic and linguistic coordinated small changes, but so far, there seems to be no explicit model of their nature and dynamics.

Dediu \& Ladd (2007) present a potential case of such a relationship, concerning two brain growth and development related genes, ASPM and Microcephalin, and linguistic tone ${ }^{\mathrm{d}}$. ASPM and Microcephalin are two human genes whose deleterious mutations cause primary recessive "high-functioning" microcephaly (Gilbert, Dobyns \& Lahn, 2005; Cox et al., 2006). Moreover, the evolution of these two genes has been accelerated in the lineage leading to humans ( $\sim 2$ favorable changes/million years), with Microcephalin evolving preponderantly during the early and $A S P M$ during the late stages of human evolution (Gilbert, Dobyns \& Lahn, 2005). Thus, these two genes represent strong candidates for key players in the evolution of human-specific traits, and,

\footnotetext{
c I totally disagree with placing convenient discontinuous boundaries (Dediu, 2006, 2007), but if such a punctual event is required, probably the emergence of Homo could be taken as the onset for this scenario (Dediu, 2007).

d This account is based on Dediu \& Ladd (2007) and Dediu (2007).
} 
even if their exact functions are not yet clear, they seem to be critical regulators of brain growth and development in humans.

Two "derived" haplogroups, one for each of these two genes, have been recently identified ${ }^{\mathrm{e}}$, showing signs of ongoing natural selection in humans (Mekel-Bobrov et al., 2005; Evans et al., 2005). They seem to have appeared recently ( $\sim 5$ and 37 thousand years ago, respectively) and $M C P H-D$ even seems to have introgressed into the modern human lineage from a different archaic form (Evans et al., 2006), thus representing one of the strongest arguments against Recent Out of Africa with Replacement (Dediu, 2007). To date, the naturally selected phenotypic effects of these haplogroups have not been found: they seem not to be connected with intelligence (Mekel-Bobrov et al., 2007), brain size (Woods et al., 2006), head circumference, general mental ability, social intelligence (Rushton et al., 2007), or the incidence of schizophrenia (Rivero et al., 2006).

Linguistic tone is a typological linguistic feature (Haspelmath et al., 2005) which, in broad terms, reflects the usage of pitch to convey differences in meaning at the level of the word (Yip 2002:1; Dediu \& Ladd, 2007). Tone is a very complex topic in linguistics and its typology is still debated, especially the case of so-called "pitch-accent languages" (Yip, 2002 or Dediu, 2007:291-293). Geographically, tone languages tend to be clustered in sub-Saharan Africa, East and South-East Asia and Central America/Caribbean/Amazonia (Maddieson, 2005; Dediu \& Ladd, 2007) and, historically, tone can be acquired and lost through ordinary processes, like the effects of voicing contrasts in obstruents (Yip, 2002:35-38; Hyman, 1978).

The proposal of Dediu \& Ladd (2007) is that $A S P M-D$ and $M C P H-D$ might determine a very small bias at the individual level in the acquisition or processing of linguistic tone, bias which can be amplified in a population through the cultural transmission of language across generations, and manifested in differences between the languages spoken by such populations. They support this hypothesis by the fact that the population frequencies of $A S P M-D$ and $M C P H-D$ correlate negatively with the use of linguistic tone by that population (see Fig. 1), even after geography and shared linguistic history have been controlled for. This correlation is highly significant and important when compared with a sample of 983 genetic variants covering the nuclear genome and 26 linguistic features representing various aspects of phonology,

\footnotetext{
${ }^{\mathrm{e}}$ Denoted in the following as $A S P M-D$ and $M C P H-D$, respectively
} 
morphology and syntax (Dediu \& Ladd, 2007; Dediu, 2007). These facts suggest that the correlation between tone, $A S P M-D$ and $M C P H-D$ is not satisfactorily explained by the "usual suspects", namely contact (genetic and linguistic), migrations or descent from a common ancestor (or a combination thereof). However, exactly these factors represent the explanation for most of the language-gene correlations detected to date.

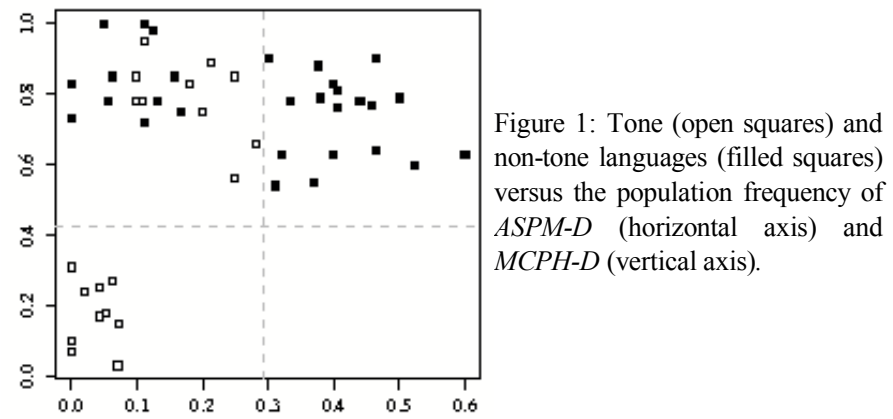

That such biases can work has been suggested by both computer (Smith, 2004; Nettle, 1999) ${ }^{\mathrm{f}}$ and mathematical (Kirby, Dowman \& Griffiths; 2007) models, but, if confirmed by further experimental studies ${ }^{\mathrm{g}}$, this would represent the first case of a genetically-influenced linguistic bias manifest at the population level.

\section{Linguistic and genetic causal correlations - the mechanism of gradual, accretionary language evolution?}

This type of bias could represent the kind of mechanism required to underlie gradual, accretionary accounts of language evolution, whereby small genetic changes can appear, influence the capacity for language in diverse populations and possibly became part of the universal, species-wide linguistic capacity. Such small genetic changes which have a linguistic biasing effect, not necessarily as their primary phenotype, can become fixed across the entire Homo sapiens species due to either genetic drift or natural selection.

In the second case, it is possible that the phenotypic trait under natural selection to be totally unrelated to language (as Dediu \& Ladd (2007) suggest is

\footnotetext{
f A recently conducted computer simulation (Dediu, in preparation) seems to suggest that only certain types of genetically-influenced linguistic biases can become manifest through cultural transmission.

$\mathrm{g}$ Such a study is currently in preparation, focusing on adult speakers.
} 
the case with $A S P M-D$ and $M C P H-D)$, or, it is also possible that it is exactly the gene's effects on language which determine its increase in frequency. Whichever the exact scenario, such a language-biasing genetic variant will induce a change in the linguistic landscape. Moreover, future genetic variants will act in this modified linguistic landscape and their fate will be influenced by the particular history of previous mutations.

This complex accretionary process, involving interactions between many genetic variants and linguistic states across evolutionary time, represents a more plausible account for the evolution of language, being able to better accommodate the data and theories originating in evolutionary biology, genetics, behavior genetics and linguistics. Therefore, to return to the three main controversies presented in the beginning, the model proposed here argues for a gradual/accretionary transition, involving a long stretch of evolutionary time and, as argued by Smith (2006), such a gradual model can also help settle the dispute concerning the nature of the protolanguage (holistic vs. synthetic).

\section{Acknowledgements}

The author was funded by an ORS Award, a Studentship from the College of HSS, the University of Edinburgh and an ESRC Postdoctoral Fellowship.

\section{References}

Bickerton, D. (2000). How protolanguage became language. In Knight, Studdert-Kennedy \& Hurford (Eds.).

Bishop, D. V. M. (2003). Genetic and environmental risks for specific language impairment in children. Intern. J. Ped. Otorhinolaryng. 6751, S143-S157.

Brighton, H. (2003). Simplicity as a driving force in linguistic evolution. PhD. Thesis, The University of Edinburgh.

Cangelosi, A., Smith, A.D.M. \& Smith, K. (Eds.) (2006). The Evolution of Language. London:World Scientific.

Christiansen, M.H. \& Kirby, S. (Eds.) (2003). Language Evolution, Oxford University Press.

Cox, J., Jackson, A., Bond, J., Woods, C. (2006). What primary microcephaly can tell us about brain growth. Trend. Molec. Med. 12, 358-366.

Crow, T. (2002a), Introduction. In Crow, T. (Ed.), The Speciation of Modern Homo Sapiens (pp. 1-20). Oxford: Ofxord University Press.

Crow, T. (2002b), Sexual selection, timing and an X-Y homologous gene: Did Homo sapines speciate on the Y chromosome? In Crow, T. (Ed.), The Speciation of Modern Homo Sapiens (pp. 197-216). Oxford: Ofxord University Press. 
Dawkins, R. (1997). Climbing Mount Improbable. Penguin Books.

Dediu, D. (2006). Mostly out of Africa, but what did the others have to say?, In Cangelosi, Smith \& Smith (Eds.) (pp. 59-66).

Dediu, D. (2007). Non-Spurious Correlations between Genetic and Linguistic Diversities in the Context of Human Evolution, $\mathrm{PhD}$ Thesis, The University of Edinburgh.

Dediu, D. \& Ladd, D.R. (2007). Linguistic tone is related to the population frequency of the adaptive haplogroups of two brain size genes, ASPM and Microcephalin. PNAS 104, 10944-10949.

Evans, P. D., Gilbert, S., Mekel-Bobrov, N., Vallender, E., Anderson, J., VaezAzizi, L. et al. (2005). Microcephalin, a Gene Regulating Brain Size, Continues to Evolve Adaptively in Humans. Science 309, 1717 - 1720.

Evans, P.D., Mekel-Bobrov, N., Vallender, E.J., Hudson, R.R. \& Lahn, B.T. (2006). Evidence that the adaptive allele of the brain size gene microcephalin introgressed into Homo sapiens from an archaic Homo lineage. PNAS 103, 18178-18183.

Fisher, S., Lai, C.S. \& Monaco, A.P. (2003). Deciphering the genetic basis of speech and language disorders. Annual Review of Neuroscience 26, 57-80.

Gerhart, J. \& Kirschner, M. (1997). Cells, embryos and evolution: toward a cellular and developmental understanding of phenotypic and evolutionary adaptability. Massachusetts: Blackwell Science.

Gilbert, S. L., Dobyns, W. B. \& Lahn, B. T. (2005). Genetic links between brain development and brain evolution. Nat. Rev.: Genetics 6, 581-590.

Haspelmath, M., Dryer, M. S., Gil, D. \& Comrie, B. (2005). The World Atlas of Language Structures. Oxford University Press.

Hurford, J. (2003), The language mosaic and its evolution. In Christiansen, M. \& Kirby, S. (Eds.) pp. pp. 38-57.

Hurford, J. R., Studdert-Kennedy, M. \& Knight C. (Eds.) (1998). Approaches to the Evolution of Language - Social and Cognitive Bases, Cambridge University Press.

Hyman, L.M. (1978). Historical tonology. In V.A. Fromkin (Ed.) Tone: $A$ Linguistic Survey (pp. 257-269). London: Academic Press.

Kirby, S. (2000). Syntax without Natural Selection: How compositionality emerges from vocabulary in a population of learners. In Knight, StuddertKennedy \& Hurford (Eds.) pp. 303-323.

Kirby, S., Dowman, M. and Griffiths, T. (2007). Innateness and culture in the evolution of language. PNAS 104, 5241-5245.

Knight, C., Studdert-Kennedy, M. \& Hurford, J.R. (Eds.) (2000). The Evolutionary Emergence of Language - Social function and the origins of linguistic form, Cambridge University Press.

Maddieson, I. (2005). Tone. In Haspelmath, Dryer, Gil, D. \& Comrie (Eds.)

Mekel-Bobrov, N., Gilbert, S. L., Evans, P. D., Vallender, E. J., Anderson, J. R., Hudson, R. R. et al. (2005). Ongoing Adaptive Evolution of ASPM, a 
Brain Size Determinant in Homo sapiens. Science 309, 1720 - 1722.

Mekel-Bobrov, N., Posthuma, D., Gilbert, S.L., Lind, P., Gosso, M.F., Luciano, M., et al. (2007). The ongoing adaptive evolution of ASPM and Microcephalin is not explained by increased intelligence. Human Molecular Genetics 16, 600 - 608.

Mithen, S. (1996). The prehistory of the mind: A search for the origins of art, science and religion. London: Thames \& Hudson.

Nettle, D. (1999). Using Social Impact Theory to simulate language change. Lingua 108, 95-117.

Pinker, S. \& Jackendoff, R. (2005). The faculty of language: what's special about it? Cognition 95, 201-236.

Plomin, R. \& Kovas, Y. (2005). Generalist genes and learning disabilities, Psychological Bulletin 131, 592-617.

Rivero, O., Sanjuán, J., Moltó, M.-D., Aguilar, E.-J., Gonzalez, J.-C., de Frutos, R., Nájera, C. (2006). The microcephaly ASPM gene and schizophrenia: A preliminary study. Schizophrenia Research 84, 427-429.

Rushton, J., Vernon, P., Bons, T. (2007). No evidence that polymorphisms of brain regulator genes Microcephalin and ASPM are associated with general mental ability, head circumference or altruism. Biol. Letters 3, 157-160.

Skelton, P. (1993). Evolution: a biological and palaeoantological approach, The Open University.

Smith, K. (2004). The evolution of vocabulary. J. Theor. Biol. 228, 127-142.

Smith, K. (2006). The protolanguage debate: bridging the gap? In Cangelosi, Smith \& Smith (Eds.) pp. 315-322.

Stringer, C. B. \& Andrews, P. (1988). Genetic and fossil evidence for the origin of modern humans. Science 239, 1263-1268.

Stromswold, K. (2001). The heritability of language: a review and metaanalysis of twin, adoption, and linkage studies. Language 77, 647-723.

Tallermann, M. (2006). A holistic language cannot be stored, cannot be retrieved, In Cangelosi, Smith \& Smith (Eds.) pp. 447-448.

West-Eberhard, M. J. (2003). Developmental plasticity and evolution. Oxford: Oxford University Press.

Woods, R., Freimer, N., De Young, J., Fears, S., Sicotte, N., Service, S. et al. (2006). Normal variants of Microcephalin and ASPM do not account for brain size variability. Human Molecular Genetics 15, 2025-2029.

Wray, A. (2000). Holistic utterances in protolanguage: the link from primates to humans. In Knight, Studdert-Kennedy \& Hurford (Eds.) pp. 285-302.

Wray, A. (2002). Dual processing in protolanguage: performance without competence. In Wray, A. (Ed.), The Transition to Language (pp. 113-137). Oxford: Oxford University Press.

Yip, M. (2002). Tone. Cambridge: Cambridge University Press. 